\title{
On Some Regularities of One-seeded Fruits Evolution
}

\author{
Tatyana I. Kravtsova \\ Komarov Botanical Institute RAS, Saint Petersburg 197376, Russia
}

\begin{abstract}
Anatomical structure of differently originated seed envelopes in one-seeded indehiscent fruits of Urticaceae and Asteraceae members is studied using light and scanning electron microscopes. It was found that in anthocarps and involucrate fruits of both families the relations between the primary (pericarp) and secondary fruit envelopes (perianth and/or involucre) were composed under complexification (union) type, and not as substitution. Numerous examples of non-homologous resemblance in fruit envelope structure indicate a high degree of adaptability of certain histological types, recurring on a different morphological basis in different phyletic lines within a family. These tissue complexes represent widely occurring types of the pericarp (Utricaceae) or pericarp and seed coat tissue union (Asteraceae). This evolutionary repetition or pseudocyclic resemblance is apparently another common regularity of one-seeded indehiscent fruits evolution in addition to those enumerated in general by Zohary (1950).
\end{abstract}

Key words: Asteraceae, Corymbium, Urticaceae, accessory envelope, fruit, non-homologous resemblance.

\section{Introduction}

Molecular-phylogenetic investigation of Angiospermae [1], detailed studies of gynoecium structure [2-4], paleobotanical findings [5], examination of morphological and anatomical fruit characters in many extant taxa have broadened our knowledge about fruit structure summarized earlier by Roth [6], especially in basal angiosperms. The origin of a carpel and the very first steps of fruit evolution remain, however, uncertain questions $[2,4,5,7]$. The notion that seemingly stayed changeless is that one-seeded indehiscent fruits (pericarp fruits [8]) of living taxa generated by the reduction of apocarpous and coenocarpous fruits, what often followed by integration with flower and inflorescence. According to the concept, this fruit represents an ultimate stage of one of general trends of fruit evolution [6, 8-12]. Deep morphological differences of fruits, their protective and dissemination functional dissimilarities are related to poly-/monospermy and dehiscence/indehiscence $[10,11,13-15]$. One-seeded indehiscent fruits are considered sometimes as very integrate systems, more

Corresponding author: Tatyana I. Kravtsova, Sc.D., leading research scientist, research fields: botany, evolutionary morphology, comparative anatomy of higher plants. E-mail: TKravtsova@binran.ru. highly organized than other fruit types, because functional correlations between their elements are stronger [11]. As was noted by Zohary [9], it is especially intriguing to trace further evolutionary changes of fruits in those groups where monospermy has become a fixed characteristic. He and the followers (e.g., Claßen-Bockhoff [16]) found, that similar morphological transformations occurred subsequently: aggregation of fruits into dense infructescences (aggregates) corresponding to functional units, differentiation of fruits to the infructescence (heterocarpy), their numerical reduction up to one, aggregation of mono- or oligomerous dense infructescences into secondary aggregates. Involvement (incorporation) of extracarpellary flower organs in fruit formation is common trend as well [6, 8, 10, 17-19].

Our observations have shown that those families are of particular interest for study fruit evolutionary trends, in which one can trace the transition of pericarp fruit (in the sense of Pijl [8]) to fruit-anthocarp (in sense of Spjut [20]); alias, where fruit as the system "fruit-seed" [18] transforms into the system "infructescence-(flower)-fruit-seed". In newly arranged anthocarps or involucrate fruits the redistribution of protective and dissemination 
functions starts again between different seed envelopes, and partial transference of functions to secondary envelope occurs.

The goal of this work was to study specific character of evolutionary transformation of this fruit type by the example of two families-Urticaceae and Asteraceae (tribe Corymbieae), the question on structure and contribution of differently originated seed envelopes to fruit formation was in the focus of attention.

\section{Materials and Methods}

Fruit structure in 253 species and some infra-specific taxa from 44 genera of the Urticaceae and in only few Asteraceae, three Corymbium species, was examined using light and scanning electron microscopes. The study was based mostly on fruits from herbarium specimens from LE, K, L, MO, VLA, $\mathrm{PE}$, and some others, partly on material from botanical gardens (seed exchange), carpological collection of Komarov Botanical Institute (St. Peterburg, Russia), greenhouses of Komarov Botanical Institute, and Main Botanic Garden of Russian Academy of Sciences (Moscow, Russia), and were collected in nature-St. Petersburg vicinity, the North Caucasus. For anatomical study, fruits were first placed in a mixture of water, $96 \%$ ethanol and glycerol in equal proportions. Material was fixed in $70 \%$ alcohol, and for thin sections in 3\% glutaraldehyde and $2 \%$ Osmium tetroxide. Cross sections 12 and $24 \mu \mathrm{m}$ thick were made in the middle part of fruits using freezing microtome, and histochemical studies were carried out to determine lignin (with phloroglucinol and sulfuric acid) and cutin (with Sudan IV). Cross and longitudinal paraffin sections $(12 \mu \mathrm{m}$ thick, stained with gentian-violet and orange or Safranin and alcian blue) were made on rotary microtome following standard procedures [21], and semi-thin sections (2-3 $\mu \mathrm{m}$ thick, stained with toluidine blue) of material embedded in Epon-Araldite epoxy resin were prepared on Reichert Ultracut R ultramicrotome. Observations were carried out and photomicrographs were taken using scanning electron microscope Jeol JSM-35C and light microscope AxioImager A1 (Carl Zeiss) equipped with digital imaging AxioCam MRc5 and software Zen 2011.

\section{Results and Analysis}

\subsection{Urticaceae}

Fruits in the nettle family develop from a pseudomonomerous gynoecium [22, 23], the ovary is unilocular with single orthotropous ovule, attached basally or subbasally. In the Urticaceae several evolutionary trends may be distinguished in fruit development [24, 25], among them partial transference of pericarp functions to the accessory fruit envelope-fruiting perianth and involucre, the development of winged and fleshy drupe-like disseminules, dense infructescences, representing functional units and bearing resemblance with true fruits. The last is often accompanied by the development of more or less fleshy or juicy fruiting perianth, promoting fruit aggregation, fleshy receptacle (Pipturus, Nothocnide, Procris) or inflorescence axes (Gyrotaenia). It should be noted that just obtaining of this qualitatively new accessory fruit envelope that resulted in emergence of the new diaspore with higher organization level; it increased fruit evolutionary plasticity, supplied the diversity of dissemination modes and fruit polymorphism (heteroanthocarpy, genetic polymorphism) in the group. Together with transformed perianth and the involucre, arising as the result of oligomerization of inflorescence in representatives of Forsskaoleae, Parietarieae and Boehmerieae the fruits sometimes acquire lignified, more or less thick cover (Hemistylus boehmerioides, Neodistemon indicum Parietaria judaica, P. cretica, certain Pouzolzia species).

It was found in the result of comparative anatomical examination [25-27] that few layered, in many genera of the same type, highly specialized pericarp, often strongly mineralized, has been formed in parallel with foregoing processes of fruit complication and 
aggregation. Strongly reduced seed coat in Urticaceae is represented by tanniniferous membrane, brown or greenish due to chloroplasts, sometimes (Urtica) adhering to the pericarp. Two-three strongly compressed layers may be distinguished in the seed coat, the exotesta is often perforated, while the endotegmen tanniniferous. The presence of tannins and endotesta cells provided with lignified thickened anticlinal walls (Boehmerieae) indicates to maintenance by the seed coat of protective role to some extent. Another function may be assumed for it, connected with respiratory metabolism during early seed development: testal aerenchima is formed in outer integument, and holes (intercellular spaces) appear in the exotesta at the stage of globular embryo. The degree of seed coat development is not in reverse correlation with pericarp structure, as it was found, e.g., in cypselas of Asteraceae [28], in one-seeded indehiscent fruits of aquatic monocotyledons Potamogeton and Zostera [29]. The differences revealed in the degree of differentiation and presence or absences of lignified cells in the testa are connected with taxonomical position of the genus. Sometimes a differentiation of seed coat and pericarp is proportional (Girardinia). The less simplified seed coat is found in archaic fruits of certain Dendrocnide species with well developed pericarp.

Further partial transference of pericarp functions to the supplementary envelope of perianth or mainly involucre is very characteristic for the Urticaceae. The new perianth function can show itself in different ways in tribes. Free 3-5-merous perianth in Elatostemeae and Urticeae is presumably membranous in fruiting stage; its specialization is connected with post-flowering growth to form sepals, completely or incompletely enveloping the fruit, sometimes perianth becomes wing-like or fleshy. In the Boehmerieae tightly adhering and inseparable fruiting perianth of divers morphological-anatomical structure is formed from tubular perianth; its important property is flexibility of structure, in several genera simultaneously with monotypic structure of the pericarp. Firstly attached to fruit, membranous and easily removable (certain Boehmeria species), it subsequently becomes inseparable and structured, acquires histological differentiation. Fleshy or juicy fruiting perianth may develop in parallel in different genera irrespective of pericarp structure; dry structured fruiting perianth is connected commonly with hard mineralized pericarp.

It is found that this evolutionary fruit transformation in the Urticaceae is not usually accompanied by displacement of its primary envelopes (Figs. 1A-1G). It is true only in respect of involucre, that may take place of thin fruiting perianth to the large extent, and of thin and considerably reduced pericarp in the case of lignified or vigorous involucre (Parietaria cretica, Gesnouinia arborea respectively). In the majority of anthocarps well developed pericarp remains. All fruit wall in the anthocarps of many Boehmerieae species with tightly adhering to the pericarp well developed structured accessory envelope is often similar with the pericarp of Urticeae members, particularly in genera Dendrocnide (Fig. 1A) and Urtica (Fig. 1E). The pericarp in such fruits, often not reduced, but wholly sclerified (Figs. 1F, 1G), becomes similar in whole or in part to sclerenchymatous endocarp, but qualitatively new due to its multilayered structure and silica containing. Parenchymatous, mucilaginous and crystalliferous zones of the anthocarps wall originate from newly formed accessory envelope of perianth. The hairs, which are capable, as is known [30] to absorb water, in the mucilaginous outer epidermis of the perianth of several Pouzolzia species (Fig. 1G) act apparently like hydrocytes in mucilaginous exocarp of Urtica.

In the Urticaceae one can identify two structural types of fruit wall, recurring on a different morphological basis in different evolutionary lines: 1) fruit wall of the pyrenarium or drupe-like anthocarps (Figs. 1A-1D), containing mucilaginous cells in its 
middle layers; 2) the fruit wall of Urtica type with mucilaginous exocarp (Figs. 1E-1G) in achene-like fruits.

Fruit fleshiness, that is the adaptation to endozoochory, was determined in primitive pyrenaria of some Dendrocnide (Fig. 1A) and Gyrotaenia species (Urticeae) and more derived fruits of Poikilospermum species (Fig. 1C) by fleshy mucilage-containing mesocarp (except soft extarcarpellate parts). In the course of fruit transformation the exocarp became a mucilage-containing layer (perhaps, in the result of decrease in cell layer number in the pericarp). This process one can observe within genus Dendrocnide, where it goes in parallel with fruiting perianth formation. In the tribe Boehmerieae the recurrence occurred: similar "drupe-like" fruit wall resulted from the union of pericarp and perianth tissues. Different combinations of these structures are possible, that lead to the similar result. In Nothocnide (Fig. 1B) and Pipturus the more or less fleshy part of the fruit wall comes from the perianth, but in Boehmeria (Fig. 1D) and Archiboehmeria - from mucilaginous exocarp covered by tubular membranous perianth. Fruit wall structure in the anthocarp of Urtica, provided with membranous fruiting perianth above mucilage-containing exocarp, one may perhaps also consider as analogous to drupe-like structure.

\subsection{Asteraceae (Corymbieae)}

In the Asteraceae an evolutionary trend towards reduction (mostly through floret sterilization) of cypsela number per fruiting capitulum is noted [9]. Resultant one-seeded fruiting head is known for several members of the asteraceous genera Artemisia, Carlina, Echinops, Gundelia, Myriocephalus [9, 31], as well as for Corymbium. The advanced asteraceous involucrate fruits rank among diaspores «beyond the level of the cypsela» [16], their increased organizational level supposedly opens new ways for adaptation.
Eames [10] mentioned genus Corymbium L. as example of extreme inflorescence reduction, up to one flower per head. This genus includes 9 species of xerophytic perennial herbs, endemic of south-western Cape Province [32]. In Corymbium species two upper involucral bracts enlarge and tightly enclose single densely hairy cypsela (Figs. 2A-2C). In spite of unclear phylogenetic relations of Corymbium, constituting presently a distinct monotypic tribe Corymbieae [33] many fruit anatomical characters are still poorly known for this isolated genus.

Our study of morphological and anatomical structure of involucrate fruit in three Corymbium species [34]-Corymbium africanum L. subsp. scabridum (Berg.) Weitz var. gramineum (Burm. f.) Weitz; $C$. glabrum L. and C. villosum L. f. permits to consider peculiarities of its structural organization, related to the presence of lignified involucre, representing additional protective seed envelope. The findings show that the bract mesophyll is more or less sclerified, sclerenchymatous middle zone consists of several layers of thick-walled, longitudinally oriented fibers (Figs. 2D, 2E). Fiber layers of overlapping bracts form continuous cylinder of mechanical tissue around the cypsela. Between involucre and cypsela wall a particular loose layer of numerous long pericarp capillary twin hairs develops (Fig. 2C); they participate in water absorption and retention. Specific differences in anatomical structure of bracts, and cypsela wall (Figs. $2 \mathrm{~F}, 2 \mathrm{G}$ ), consisting of membranous pericarp, thin parenchymatous seed coat with thickened cutinized outer cell walls in the exotesta and structureless endosperm are detected. It is found that the less simplified wall without folds is characteristic for the largest cypsela of $C$. villosum, whereas thin and strongly costate (folded) cypsela wall-for the smallest cypsela of $C$. africanum subsp. scabridum var. gramineum (Figs. 2C, 2F). The involucral bracts differ by fiber zone thickness and cell layer's number, chlorenchyma topography, outer epidermis structure, small-celled lignified (Fig. 2E) or large-celled 


\section{Pericarp}

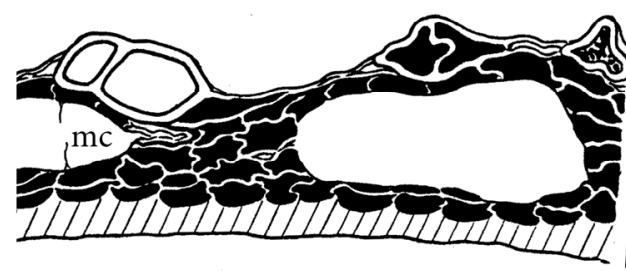

A

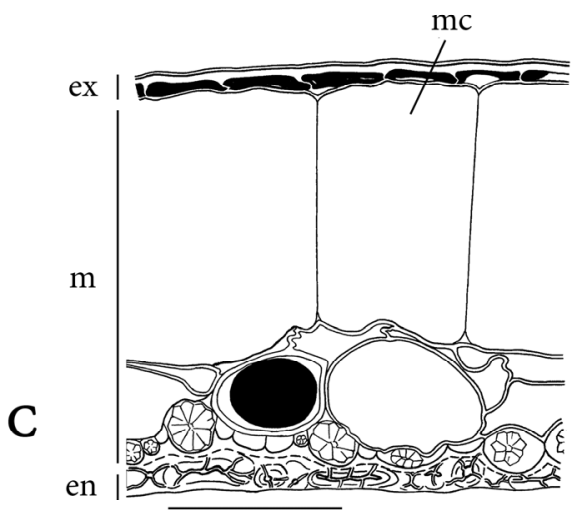

\section{Drupe-like fruits}
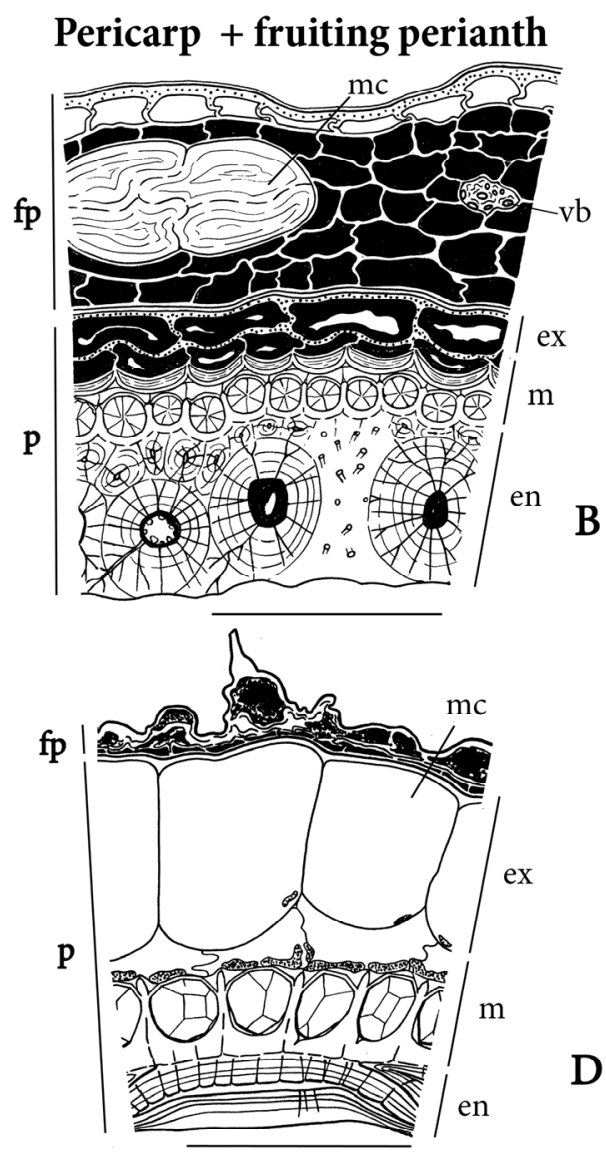

$\mathrm{D}$

Achene-like fruits
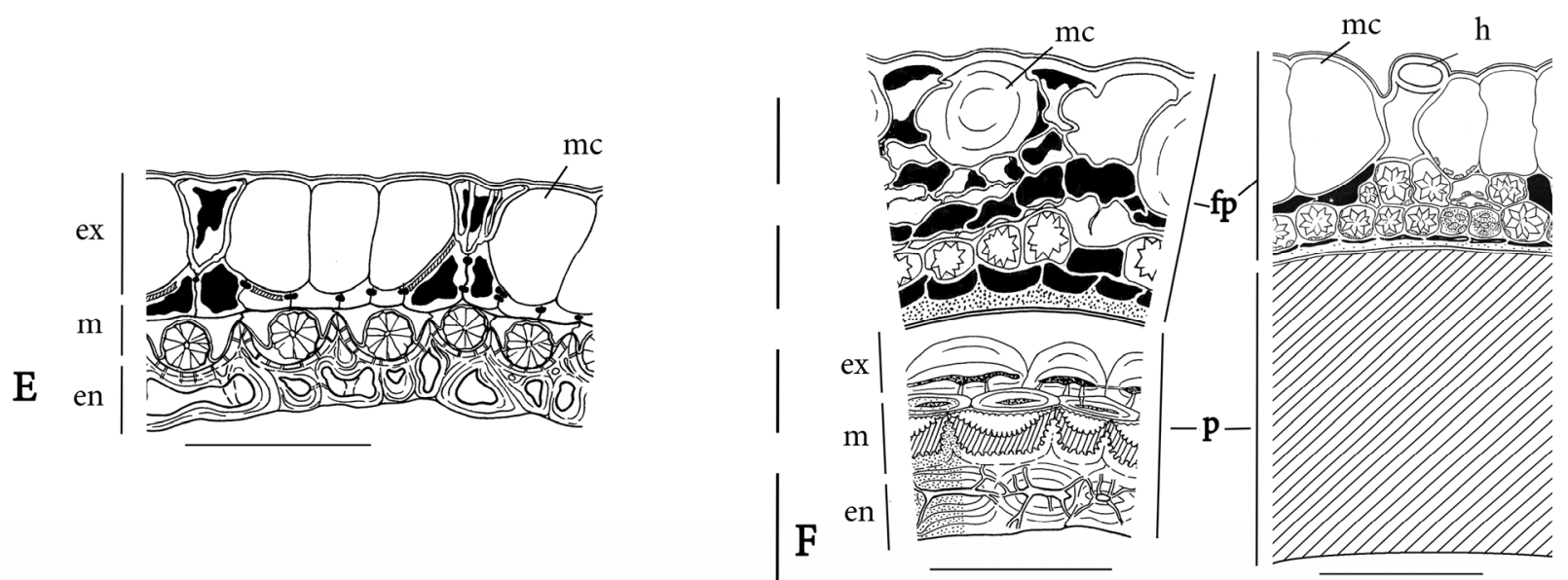

G

Fig. 1 Non-homologous resemblance of fruit wall structure in members of the Urticaceae.

A-G, pericarp and fruiting perianth in cross section: (A) Dendrocnide meyeniana (Walp.) Chew f. meyeniana, (B) Nothocnide mollissima (Blume) Chew, (C) Poikilospermum microstachys (Barg. Petr.) Merr., (D) Boehmeria japonica Miq., (E) Urtica urens L., (F) Pouzolzia sanguinea (Blume) Merrill var. cinerascens (Blume) Wedd., (G) Pouzolzia laevigata (Poir.) Gaudich., en—endocarp, ex-exocarp, $\mathrm{fp}$-fruiting perianth, $\mathrm{h}$ —hair, $\mathrm{m}$-mesocarp, mc-mucilaginous cell, $\mathrm{p}$ - pericarp, vb—vascular bundle; tannins marked by black. Scale bars $50 \mu \mathrm{m}$. 
A
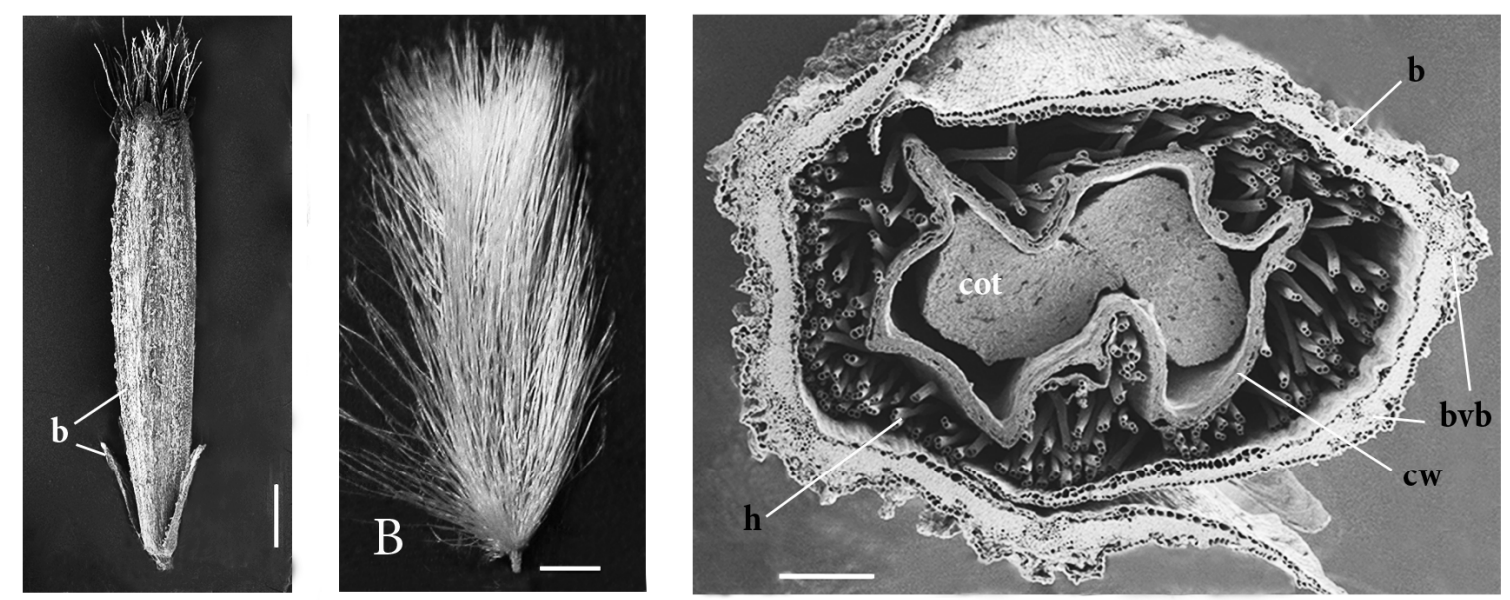

C
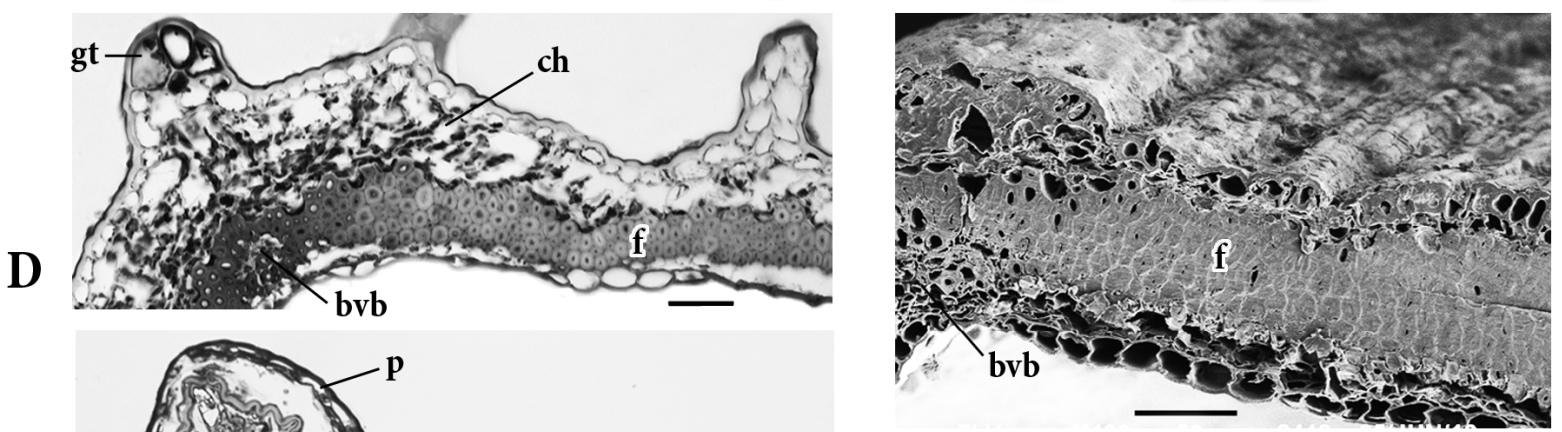

$\mathbf{E}$
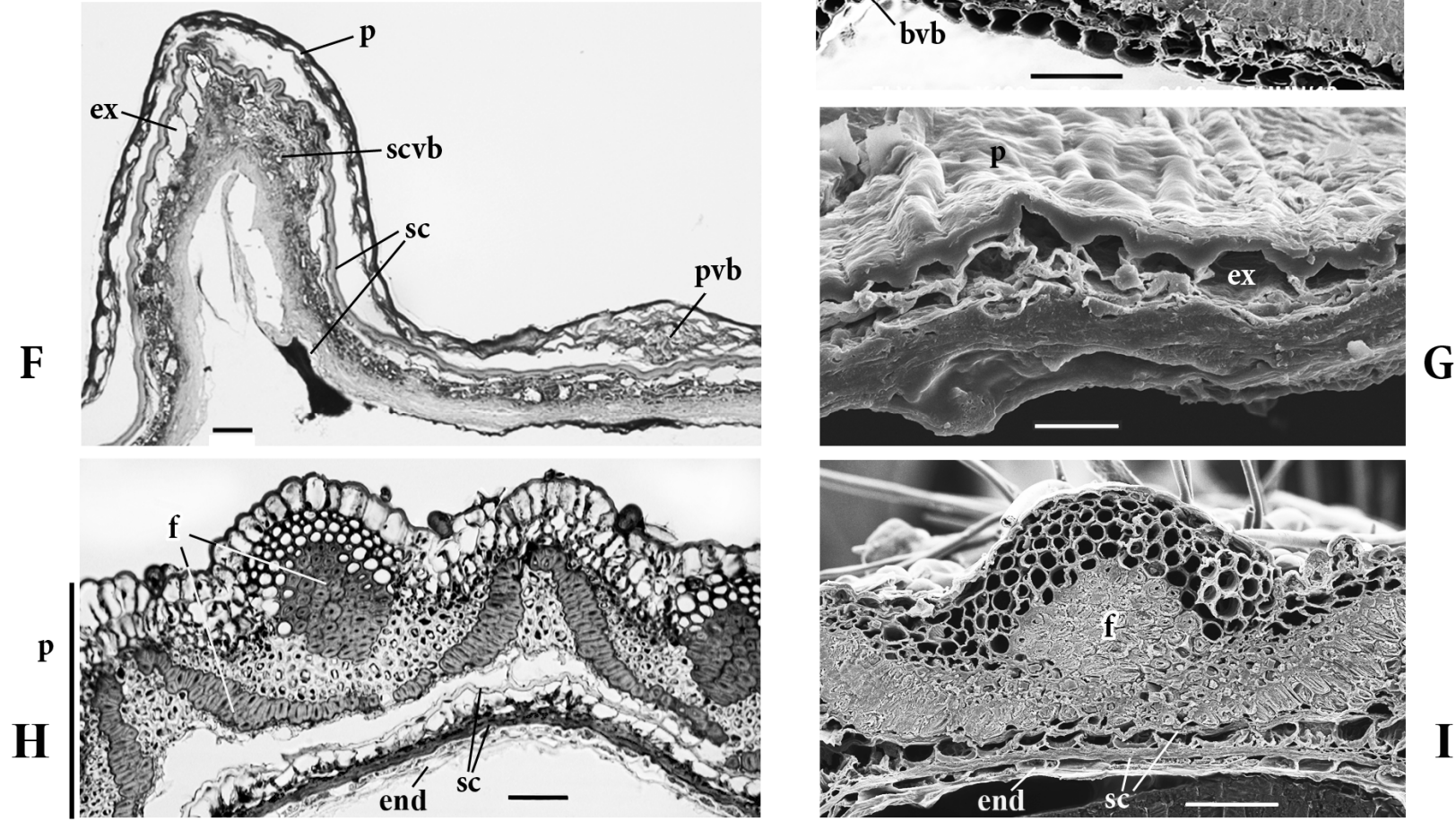

Fig. 2 Fruit structure in Corymbium and Vernonia species.

A, C, D, F-C. africanum subsp. scabridum var. gramineum: (A) involucrate fruit, (C) involucrate fruit in cross section, (D) involucre bract in cross section, (F) cypsela wall in cross section, B, E, G-C. glabrum: (B) cypsela, (E) involucre bract in cross section, (G) cypsela wall in cross section, H, I-cypsela wall of Vernonia anthelmintica (L.) Willd. in cross section (LM, and SEM, respectively), b-bract, bvb-bract vascular bundle, ch—chlorenchyma, cot—cotyledon, cw-cypsela wall, end—endosperm, ex-exotesta, f-fibers, gt—glandular trichome, h-twine hair, $\mathrm{p}$ - pericarp, pvb-pericarp vascular bundle, sc - seed coat, $\mathrm{scvb}$ - seed coat vascular bundle. Scale bars, $\mathrm{A}, \mathrm{B}=1000 \mu \mathrm{m}, \mathrm{C}=200 \mu \mathrm{m}, \mathrm{D}, \mathrm{E}, \mathrm{H}, \mathrm{I}=50 \mu \mathrm{m}, \mathrm{F}, \mathrm{G}=20 \mu \mathrm{m}$. 
parenchymatous, bearing one or two types of glandular trichome (Fig. 2D). The degrees of secondary (involucre) and primary cypsela envelopes development are in inverse relations, what indicates to possible functional coordination between them: the pericarp and seed coat of $C$. africanum subsp. scabridum var. gramineum and $C$. glabrum are simplified as compared to $C$. villosum with its less sclerified involucre. Tannins and characteristic cell wall thickenings remained in the exotesta cells of this species. It may be noticed that the partial loss of mechanical property by the pericarp goes with maintenance (perhaps, increasing) of its role in the regulation of moisture conditions.

The comparison of cypsela structure in Corymbium species with members of tribe Vernonieae (according to all available published data), earlier including this genus, has shown that the compound wall of involucrate fruit in Corymbium species is histologically similar (except for hairy zone) with cypsela wall in many Vernonia and Elephantopus species [35-37], for instance in $V$. anthemintica (Figs. $2 \mathrm{H}, 2 \mathrm{I})$. Their common traits are (1) the peripheral fiber zone originated either from sheathing bracts or from the pericarp, and (2) inner parenchymatous zone formed by the pericarp together with the seed coat (Corymbium) or only by seed coat (Vernonieae). Roth [6] observed, that in the pericarp of Asteraceae members an outer hypoderm is usually differentiated as discontinuous sclerenchymatous layer, what suggests that mentioned above pattern of fruit wall histological structure recurs more than once within the family.

\section{Discussion}

The results obtained show, that in both groups under consideration fruit evolutionary transformation usually is not accompanied by complete displacement of primary inner envelope by newly formed outer one. The relations between the pericarp and fruiting perianth/involucre compose here under complexification (union) type [38], and not as substitution, apparent in several other groups - certain members of Nyctaginaceae [39-41], Dipsacaceae [42], where the pericarp is reduced almost completely, in the second family together with perianth. This study thus demonstrates that one-seeded indehiscent fruits in different taxa may correspond to different morphological-functional systems, differing both in composition (a system "fruit-seed" transforms to "flower-fruit-seed inflorescence-(flower)-fruit-seed" one), and by their interrelationships, substitution or structural complexification.

The examples of analogy in fruit envelope structure may be observed in both families. Certain histological types of fruit wall organization recur on a different morphological basis (in incompletely homologous fruits) in different phyletic lines within the family. This complex of differently originated tissues is one of widely distributed within a family histological types of the pericarp (Urticaceae) or pericarp and seed coat union (Asteraceae); this pattern is apparently highly adaptive in these families.

The non-homologous similarity revealed is another example of "evolutionary repetition" $[8,16]$ or pseudocyclic similarity $[43,44]$, here on a histological level. This phenomenon is usually accounted by the adaptability, but it was noted more than once that its true reasons remain uncertain $[44,45]$. The repeated recurrence of the same morphological feature in the evolution of different animal groups (in every group its own) Tatarinov [45] refer to unclear problems of phylogenetic parallelisms.

It may be supposed that anatomical resemblance of incompletely homologous fruits within a family is another common regularity of one-seeded indehiscent fruit evolution (at least for certain families). However further investigations of the issue are needed.

Corner [46, 47] also assumed the transference of functions in seeds in respect of anatomical characters: functions of an aril (he considered it to be a primitive character) were transferred in the view of him to 
sarcotesta and placenta. Stebbins [17], who observed repeatedly transference of functions in seed evolution of many angiosperm taxa, connected it with arid or semi-arid climate of mountain habitat. Our data on Corymbium and Parietaria (Urticaceae) add to his numerous examples. Several Parietaria species are adapted to rocky habitats with periodical drought. As it follows from our study and was noted earlier [16], characteristic feature of accessory cover in such complex fruits is lignification; this peculiarity may affect considerably the germination behavior [48-50].

The results obtained are of interest in connection with a hypothesis of Stebbins [17], who suggested that "repeated cycles based upon transfers of the function of a particular structure from protecting the developing ovules to aiding the dispersal of mature seeds" were similar with those cycles in pre-angiospermous seed plants, what involves the cupula wall of certain seed ferns. It is not impossible that seed envelope in the new diaspore of angiosperms, in the first fruit, was (at least in some taxa) «evolutionary repetition», bearing histological resemblance with seed coat in members of ancestral group. The carpels of early extant and early fossil angiosperms appear to contain only one or a small number of ovules $[4,5]$. The dehiscence of primitive fruits, which are thought to develop from ascidiate carpels, is presently debatable question (see, for example, Sokoloff et al. [7]). Recent findings in Hydatellaceae showed that dehiscence may be of quite specific character, and exceeds the limits of existing so far conception. In certain Hydatella one-seeded apocarpous fruit exploded, and at the same time separated from maternal plant, is very similar with indehiscent one, for only thin pericarp ribs detach from the seed, and three pericarp valves remain closely connected with it [7, 51].

\section{Conclusions}

The appearance of one-seeded indehiscent fruits in many taxa of angiosperms was accompanied by their further similar morphological transformations, enumerated generally by Zohary [9]. Non-homologous resemblance of histological structure of seed envelopes in such not completely homologous fruits (provided or not with accessory cover) was revealed within the Urticaceae and certain groups of Asteraceae. We suppose that this case of evolutionary repetition may represent another common regularity of evolution of one-seeded indehiscent fruits (at least for several families) and needs further investigation in other angiosperm and pre-angiosperm groups.

\section{Acknowledgments}

The research was done using equipment of The Core Facility Center "Cell and Molecular Technologies in Plant Science" at the Komarov Botanical Institute RAS (St.-Petersburg, Russia). The author appreciates curators of Herbaria, from which material was received, L.A. Kartseva, the head of scanning electron microscopy branch of the Core Facility Centre for technical assistance in SEM studies, and Dr. A.N. Ivanova (Komarov Botanical Institute) for assistance in translation. The present study was supported by the Russian Foundation for Basic Research under grant 13-04-0852.

\section{References}

[1] Angiosperm Phylogeny Group (APG) 2009. An update of the Angiosperm Phylogeny Group classification for the orders and families of flowering plants: APG III, Bot. J. Linn. Soc. 161: 105-21.

[2] Endress, P. K., and Igersheim, A. 2000. "Gynoecium Structure and Evolution in Basal Angiosperms." Int. J. Plant Sci. 161 (6): 211-23.

[3] Soltis, D. E., Soltis, P. S., Endress, P. K., and Chase, M. W. 2005. Phylogeny and evolution of Angiosperms, Sunderland.

[4] Endress, P. K., and Doyle, D. E. 2009. "Reconstructing the Ancestral Angiosperm Flower and Its Initial Specializations." Amer. J. Bot. 96 (1): 22-66.

[5] Friis, E. M., Crane, P. R., and Pedersen, K. R. 2011. Early flowers and angiosperm evolution, Cambridge University Press.

[6] Roth, I. 1997. "Fruits of Angiosperms, Encyclopedia of Plant Anatomy." Berlin: G. Borntraeger 10 (1): 666. 
[7] Sokoloff, D. D., Remizova, M. V., Macfarlane, T. D., Conran, J. G., Yadav, S. R., and Rudall, P. J. 2013. "Comparative Fruit Structure in Hydatellaceae (Nymphaeales) Reveals Specialized Pericarp Dehiscence in Some Early-divergent Angiosperms with Ascidiate Carpels." Taxon 62 (1): 40-61.

[8] L. van der Pijl, Principles of dispersal in higher plants (3 ed.), Berlin etc., Springer, 1982.

[9] Zohary, M. 1950. "Evolutionary Trends in the Fruiting Head of Compositae." Evolution 4 (2): 103-9.

[10] Eames, A. J. 1964. The morphology of Angiosperms, Moscow: Mir. (In Russian)

[11] Vasilewskaya, V. K., and Melikyan, A. P. 1982. "On Origin and General Trends of Seed and Fruit Evolution in Angiosperms." Herald of Leningrad Univ. 9: 23-30. (in Russian)

[12] Bobrov, A. V. F. Ch., Melikyan, A. P., and Romanov, M. S. 2009. Morphogenesis of fruits of Magnoliophyta, Moscow: Libricom (in Russian).

[13] Levina, R. L. 1987. Morphology and ecology of fruits, Leningrad: Nauka, (in Russian).

[14] Devyatov, A. G., and Ermilova, I. Y. 2002. "The Change of the Fruit and Seed Structure in Connection with Origin of Single-seeded Diaspores in the Tribe Caryophylleae." Bull. Soc. Nat. Mosc., Sect. Biol. 107: 69-73. (in Russian)

[15] Devyatov, A. G., Korolkova, E. O., and Polevova, S. V. 2003. "Change of the Morpho-anatomical Structure of Fruits and Seeds in the Tribe Paronychieae (Caryophyllaceae) in Connection with Origin of Single-seeded Fruits.” Bull. Soc. Nat. Mosc., Sect. Biol. 108: 67-70. (in Russian)

[16] Claßen-Bockhoff, R. 1994. "Functional Units beyond the Level of the Capitulum and Cypsela in Compositae." In P.D.S. Caligari, D.J.N. Hind (Eds), Compositae: biology and utilization, Proceedings of the International Compositae Conference, Kew. (D.N. N. Hind, Ed.-in Chief) 2 (1996): 129-60.

[17] Stebbins, G. L. 1970. "Transference of Function as a Factor in the Evolution of Seed and Their Accessory Structures." Israel J. Bot. 19 (2-3): 59-70.

[18] Melikyan, A. P. 1981. "On Some General Tendencies and Specialization of Fruits, in C.M. Sitnik (Ed.), Problems of Evolutionary Morphology and Biochemistry in Systematics and Phylogeny of Plants." Kiev: Naukova Dumka: 117-125. (in Russian)

[19] Takhtajan, A. 1991. Evolutionary trends in flowering plants, N.Y.: Columbia Univ. Press.

[20] Spjut, R. W. 1994. "A Systematic Treatment of Fruit Types.” Mem. New York Bot. Gard. 70: 1-182.

[21] Prozina, M. N. 1960. Botanical microtechniques, Moscow: Vysschaya Schkola. (in Russian)

[22] Bechtel, A. R. 1921. "The Floral Anatomy of the
Urticales." Amer. J. Bot. 8 (8): 386-410.

[23] Eckardt, T. 1937. "Untersuchungen über Morphologie, Entwicklungsgeschichte und systematische bedeutung des pseudomonomeren Gynoeceums." Nova Acta Leopoldina 5 (26): 1-112.

[24] Kravtsova, T. I. 2003. On the basic directions of fruit structural evolution in Urticaceae family, in A.A. Pautov (Ed.), Questions of comparative and ecological anatomy of plants, St. Petersburg: St. Petersburg Univ. Press, pp.102-126. (in Russian)

[25] Kravtsova, T. I. 2009. Comparative carpology of the Urticaceae Juss., Moscow: KMK Scientific Press Ltd. (in Russian)

[26] Kravtsova, T. I., Friis, I., and Wilmot-Dear, C. M. 2000. "Morphology and Anatomy of Fruits in New World Boehmeria in Relation to Taxonomy." Kew Bull. 55 (1): 43-62.

[27] Kravtsova, T. I., Friis, I., and Wilmot-Dear, C. M. 2003. "Morphology and Anatomy of Fruits in Pouzolzia (Urticaceae) in Relation to Taxonomy." Kew Bull. 58 (2): 297-327.

[28] Melikyan, A. P., and Muradyan, L. G. 1975. "The Main Directions of Fruit Wall and Seed Coat Evolution in Subtribe Chrysantheminae (Asteraceae)." Bot. Zhurn. (St. Petersburg) 60 (8): 1123-33. (in Russian)

[29] Teryokhin, E. S. 1996. Seed and seed reproduction, Sankt Petersburg: Mir i semja-95. (in Russian)

[30] Uphof, J. C. 1962. "Plant Hairs, Handb. Pflanzenanat." Abt.: Histologie 4 (5): 1-206.

[31] Froebe, H. A., and Claßen, R. 1987. "Kritische Evaluation zur Deutung der Spreublattkomplexe von Carlina L." Flora 179: 445-52.

[32] Weitz, F. M. 1990. "A Taxonomic Revision of the Genus Corymbium (Asteraceae)." Mitt. Inst. Allg. Bot. Hamburg 23b: 631-42.

[33] Nordenstam, B., Funk, V., Corymbieae, Funk, V. A., Susanna, A., Stuessy, T., and Bayer (Eds), R. 2009. "Systematics, Evolution, and Biogeography of Compositae." IAPT (Vienna) 23: 487-91.

[34] Kravtsova, T. I. 2014. "Fruit Structure in Members of Corymbium (Corymbieae, Asteraceae)." Bot. Zhurn. (St. Petersburg) 99 (3): 268-81. (in Russian)

[35] Misra, S. 1972. "Floral Morphology of the Family Compositae. IV. Tribe Vernonieae-Vernonia anthelmintica." Bot. Mag. Tokyo 85 (999): 187-99.

[36] Pullaiah, T. 1979. "Embryology of Adennostemma, Elephantopus and Vernonia (Compositae)." Bot. Notis. 132 (1): 51-6.

[37] Pandey, A. K., and Singh, R. P. 1980. "Development and Structure of Seeds and Fruits in Tribe Vernonieae-Some Vernonia and Elephantopus Species." Flora 169 (5): 443-52. 
[38] Mamkaev, Yu. V. 1991. "Methods and Regularities of Evolutionary Morphology, in E.I. Vorobjeva, A.A. Vronsky (Eds), Modern Evolutionary Morphology.” Kiev: Naukova Dumka: 33-56. (in Russian)

[39] Heimerl, A. 1887. Beiträge zur Anatomie der Nyctagineen I. Zur Kenntnis des Blüthenbaues und der Fruchtentwicklung einiger Nyctagineen, Denkschr. Akad. Wiss. Wien 33 (2): 61-78.

[40] Heimerl, A. 1934. Nyctaginaceae, in: A. Engler, H. Harms (Eds), Die Naturlichen Pflanzenfamilien, 2nd ed. Leipzig: Engelmann, 16c, pp 86-134.

[41] Sukhorukov, A. P., Mavrodiev, E. V., Struwig, M., Nilova, M. V., Dzhalilova, K. K., Balandin, S. A., Erst, A., and Krinitsina, A. A. 2015. "One-seeded Fruits in the Core Caryophyllales: Their Origin and Structural Diversity." Plos. One 10 (2): 1-38.

[42] Mayer, V., and Ehrendorfer, F. 1999. "Fruit Differentiation, Palynology, and Systematics in the Scabiosa Group of Genera and Pseudoscabiosa (Dipsacaceae)." Pl. Syst. Evol. 216 (1-2): 135-66.

[43] Gaussen, H. 1952. L'évolution pseudocyclique, Année. Boil. 28 (7-8): 207-25.

[44] Kuznetsova, T. V. 1986. "The Pseudocyclic Resemblance in Higher Plants." Journal of General Biology 47 (2): 218-33. (in Russian)
[45] Tatarinov, L. P. 1987. Essays on a theory of evolution, Moscow: Nauka. (in Russian)

[46] Corner, E. J. H. 1949. "The Durian Theory or the Origin of the Modern Tree." Ann. Bot. N. S. 13 (52): 367-414.

[47] Corner, E. J. H. 1953. The Durian theory extended-I. Phytomorphology 3 (4): 465-7.

[48] Butnik, A. A. 1972. The structure of fruit envelopes in the goosefoot family, in: Morphological- biological and structural peculiarities of fodder plants, Tashkent: FAN, pp 17-28. (in Russian)

[49] Butnik, A. A. 1981. "The Carpological Characteristics of the Chenopodiaceae Representatives." Bot. Zhurn. 66 (10): 1433-43. (in Russian)

[50] Mayer, V. 1995. "The Epicalyx in Fruits of Scabiosa and Tremastelma (Dipsacaceae): Anatomy and Ecological Significance.” Bot. Jahrb. Syst. 117 (3): 333-57.

[51] Endress, P. K. 1996. "Evolutionary Aspects of Fruits in Basal Flowering Plants, Norske Vidensk-Akad., Mat.-Naturvidensk.” Kl. Avh. N. S. 18: 21-32.

[52] Sokoloff, D. D., Remizova, M. V., Macfarlane T. D., and Rudall, P. J. 2008. "Classification of the Early-divergent Angiosperm Family Hydatellaceae: One Genus Instead of Two, Four New Species and Sexual Dimorphism in Dioecious Taxa." Taxon 57 (2): 179-200. 